\title{
Editorial: Character, responsibility, and well-being: influences on mental health and constructive behavior patterns
}

\author{
Danilo Garcia ${ }^{1,2 *}$, Ann-Christine Andersson Arntén ${ }^{1}$ and Trevor Archer ${ }^{1,3}$ \\ ${ }^{1}$ Network for Empowerment and Well-Being, Gothenburg, Sweden, ${ }^{2}$ Centre for Ethics, Law and Mental Health, Institute of \\ Neuroscience and Physiology, University of Gothenburg, Gothenburg, Sweden, ${ }^{3}$ Department of Psychology, University of \\ Gothenburg, Gothenburg, Sweden
}

Keywords: character, personality, well-being, responsibility, agency, communion, spirituality

Character can be defined as self-aware knowledge that helps the individual to set goals, values, and ethical principles (Cloninger, 2004). This meta-cognitive dimension of human personality involves "Theory of Mind," and is positively related to measures of well-being, mental health, and constructive behavior patterns. Research from at least three different fields, cultural (Shweder et al., 1997), personality (Cloninger, 2004), and social psychology (Abele and Wojciszke, 2007) suggest that character can be organized along three broad principles: agency, which is related to the autonomy and the fulfillment and enhancement of the self; communion, which is related to engagement in the protection and relations to others such as families, companies or nations; and spirituality, which is related to the human ability to transcend the self and find and interconnection with all life and appreciation of the whole world around us (Haidt, 2006; Cloninger, 2013).

OPEN ACCESS

Edited and reviewed by: Marcel Zentner,

University of Innsbruck, Austria

*Correspondence: Danilo Garcia,

danilo.garcia@icloud.com

Specialty section:

This article was submitted to Personality and Social Psychology, a section of the journal Frontiers in Psychology

Received: 21 June 2015 Accepted: 13 July 2015 Published: 29 July 2015

Citation: Garcia D, Andersson Arntén A-C and Archer T (2015) Editorial: Character, responsibility, and well-being: influences on mental health and constructive behavior patterns.

Front. Psychol. 6:1079.

doi: 10.3389/fpsyg.2015.01079
Using the Temperament and Character Inventory (Cloninger et al., 1993) researchers have found that Self-directedness (i.e., agency), Cooperativeness (i.e., communion), and Self-transcendence (i.e., Spirituality) are associated to high levels of happiness, psychological well-being, and less violent behavior (Garcia et al., 2013, 2015; Nima and Garcia, 2015; Mousavi et al., 2015). Moreover, low Self-directedness and Cooperativeness is recurrent among individuals with all types of mental health problems, such as, depression, schizophrenia, anxiety disorder, autism spectrum disorders, attention deficit/hyperactivity disorder, and etcetera. Self-transcendence, in coherence with Self-directedness and Cooperativeness, guides the individual to seek selfrealization in harmony with others and nature in the changing world (Cloninger, 2013). Seeing character as self-awareness of the self in three dimensions has also been associated to human responsibility and empowerment (Nima et al., 2012; Schütz et al., 2013a,b; Cloninger and Garcia, 2015).

In this Research Topic researchers offer their perspective on character, responsibility, and well-being. Ruch and his colleagues, using other measures for character, offer a series of articles ranging from life satisfaction among religious people (Berthold and Ruch, 2014) to good character in school (Wagner and Ruch, 2015). Abele develops the idea of how communal values need to be pursued in agentic ways (Abele, 2014), while Garcia and his colleagues give an insight into the possible use of charactercentered teams at work places (e.g., Garcia et al., 2014a) and also its etiology in adolescence (Garcia et al., 2014b). Continuing this line, Jeppsson (2014) gives a philosophical perspective on responsibility in the field of criminal justice. Finally, Moreira et al. (2015) show the importance of character and its relation to well-being during adolescence, while Nilsson (2014) gives a critical opinion of the need of 
introducing the perspective of worldview when studying the association between personality and well-being.

With this range of different takes on the interactions between character, responsibility and well-being we hope to give a new perspective on the investigation of personality's role on human health and well-being.

\section{References}

Abele, A. E. (2014). Pursuit of communal values in an agentic manner: a way to happiness? Front. Psychol. 5:1320. doi: 10.3389/fpsyg.2014.01320

Abele, A. E., and Wojciszke, B. (2007). Agency and communion from the perspective of self versus others. J. Pers. Soc. Psychol. 93, 751-763. doi: 10.1037/0022-3514.93.5.751

Berthold, A., and Ruch, W. (2014). Satisfaction with life and character strengths of non-religious and religious people: it's practicing one's religion that makes the difference. Front. Psychol. 5:876. doi: 10.3389/fpsyg.2014. 00876

Cloninger, C. R. (2004). Feeling Good: The Science of Well-being. New York, NY: Oxford University Press.

Cloninger, C. R. (2013). What makes people healthy, happy, and fulfilled in the face of current world challenges? Mens Sana Monogr. 1, 16-24. doi: 10.4103/09731229.109288

Cloninger, C. R., and Garcia, D. (2015). "The heritability and development of positive affect and emotionality," in Genetics of Psychological Well-Being - The Role of Heritability and Genetics in Positive Psychology, ed M. Pluess (New York, NY: Oxford University Press), 97-113.

Cloninger, C. R., Svrakic, D. M., and Przybeck, T. R. (1993). A Psychobiological model of temperament and character. Arch. Gen. Psychiatry 50, 975-989.

Garcia, D., Ghiabi, B., Rosenberg, P., Nima, A. A., and Archer, T. (2015). Differences between affective profiles in temperament and character in salvadorians: the self-fulfilling experience as a function of agentic (Selfdirectedness) and communal (Cooperativeness) values. Int. J. Happiness Dev. 2, 22-37. doi: 10.1504/IJHD.2015.067592

Garcia, D., Lindskär, E., and Archer, T. (2014a). To schedule or not to schedule? Agentic and cooperative teams at call centers. Front. Psychol. 5:999. doi: 10.3389/ fpsyg.2014.00999

Garcia, D., Nima, A. A., and Archer, T. (2013). International note: temperament and character's relationship to subjective well-being in salvadorian adolescents and young adults. J. Adolesc. 36, 1115-1119. doi: 10.1016/j.adolescence.2013.08.018

Garcia, D., Stråge, A., Lundström, S., Radovic, S., Brändström, S., Råstam, M., et al. (2014b). Responsibility and cooperativeness are constrained, not determined. Front. Psychol. 5:308. doi: 10.3389/fpsyg.2014.00308

Haidt, J. (2006). The Happiness Hypothesis: Finding Modern Truth in Ancient Wisdom. New York, NY: Basic Books.

Jeppsson, S. M. I. (2014). Responsibility problems for criminal justice. Front. Psychol. 5:821. doi: 10.3389/ fpsyg.2014.00821

\section{Acknowledgments}

This Research Topic was funded with support from AFA Insurance (Dnr. 130345) and the Bliwa Stiftelsen. The funders had no role in study design, data collection and analysis, decision to publish, or preparation of any of the manuscripts.

Moreira, P. A. S., Cloninger, C. R., Dinis, L., Sá, L., Oliveira, J. T., Dias, A., et al. (2015). Personality and well-being in adolescents. Front. Psychol. 5:1494. doi: 10.3389/fpsyg.2014.01494

Mousavi, F., Rozsa, S., Nilsson, T., Archer, T., Anckarsäter, H., and Garcia, D. (2015). Persistence, not self-directedness, cooperativeness or self-transcendence, is related to twins' cognitive abilities. (In press).

Nilsson, A. (2014). A non-reductive science of personality, character, and wellbeing must take the person's worldview into account. Front. Psychol. 5:961. doi: 10.3389/fpsyg.2014.00961

Nima, A. A., Archer, T., and Garcia, D. (2012). Adolescents' happiness-increasing strategies, temperament, and character: mediation models on subjective wellbeing. Health 4, 802-810. doi: 10.4236/health.2012.410124

Nima, A. A., and Garcia, D. (2015). Factor structure of the Happiness-Increasing Strategies Scales (H-ISS): activities and coping strategies in relation to positive and negative affect. PeerJ 3:e1059. doi: 10.7717/peerj.1059

Schütz, E., Archer, T., and Garcia, D. (2013a). Character profiles and adolescents' self-reported affect. Pers. Individ. Diff. 54, 841-844. doi: 10.1016/j.paid.2012.12.020

Schütz, E., Sailer, U., Nima, A., Rosenberg, P., Andersson Arntén, A.-C., Archer, T., et al. (2013b). The affective profiles in the USA: happiness, depression, life satisfaction, and happiness- increasing strategies. Peer J. 1:e156. doi: 10.7717/peerj.156

Shweder, R. A., Much, N. C., Mahapatra, M., and Park, L. (1997). “The 'Big Three' of morality (autonomy, community, divinity) and the 'Big Three' explanations of suffering," in Morality and Health, eds M. Brandt and P. Rozin (New York, NY: Routledge), 119-172.

Wagner, L., and Ruch, W. (2015). Good character at school: positive classroom behavior mediates the link between character strengths and school achievement. Front. Psychol. 6:610. doi: 10.3389/fpsyg.2015.00610

Conflict of Interest Statement: The authors declare that the research was conducted in the absence of any commercial or financial relationships that could be construed as a potential conflict of interest.

Copyright (C) 2015 Garcia, Andersson Arntén and Archer. This is an open-access article distributed under the terms of the Creative Commons Attribution License (CC $B Y)$. The use, distribution or reproduction in other forums is permitted, provided the original author(s) or licensor are credited and that the original publication in this journal is cited, in accordance with accepted academic practice. No use, distribution or reproduction is permitted which does not comply with these terms. 